\title{
Artistic Invention as Tradition in the Portrait Painting of Late-Colonial Lima
}

\section{Invención artística como tradición en los retratos limeños del final de la época colonial}

Artículo recibido el I2 de abril de 20I7; devuelto para revisión el 20 de junio de 20I7; aceptado el 26 de abril de 20I8, https://doi.org/Io.2220I/iie.I87003062e.2018.113.2655

Emily A. Engel Independent scholar; emilyaengel@gmail.com.

Líneas de investigación La política de representación visual en la América del Sur virreinal; subjetividad, negociación política y autoridad en el retrato latinoamericano colonial; culturas visuales de la memoria y la historia en el Perú.

Lines of research The politics of visual representation in viceregal South America; subjectivity, political negotiation, and authority in late-colonial Latin American portraiture; visual cultures of memory and history in Peru.

Publicaciones más relevantes

Editado en colaboración con Thomas B.F. Cummins, Juan Ossio y Barbara Anderson, Manuscript Cultures in Colonial Mexico and Peru: New Questions and Approaches (Los Angeles: Getty Publications, 20I5); autora de"Changing Faces: Royal Portraiture and the Manipulation of Colonial Bodies in the Viceroyalty of Peru", in Spanish Royal Patronage: Portraits as Propaganda, ed. Ilenia Colon (Cambridge: Cambridge University Press, 2018), I49-169; "Manifesting Visual Battlefields in Early Republican South America," in Empire and Colonial Art/Império e Arte Colonial, ed. Maria Joao Castro (Lisboa: ArTravel, 2017): "Official Portraiture and Authority in Late-Colonial Lima and Buenos Aires", Dieciocho 33.I (2010): I69-206; "Visualizing a Colonial Peruvian Community in the Eighteenth-Century Paintings of Our Lady of Cocharcas", Religion and the Arts I3 (2009): 299-339.

Resumen José Joaquín Bermejo, Cristóbal de Aguilar, Cristóbal de Lozano y Pedro Díaz no son nombres muy conocidos fuera del Perú. Sin embargo, estos artistas son algunos de los pintores más influyentes en la historia del arte del mundo del siglo XviII. Como los pintores de retratos de primera clase en la capital mundial de Lima, estos artistas hacen visibles las identidades de los agentes del poder que ayudaron a dar forma al imperio iberoamericano en su crepúsculo. Colectivamente, 
Bermejo, Aguilar, Lozano, Díaz y facilitó un cambio pictórico dentro de un género tradicional que requiere arcaísmo y la repetición para mantener su relevancia cultural. Sus retratos terminados demuestran visualmente una disonancia emergente entre la innovación artística y la tradición pictórica. A través de un examen de sus corpus de trabajo de finales del siglo xviII, este artículo demuestra cómo los artistas ajustan la representación de los cuerpos de élite en el retrato para reflejar la sutil desintegración de un cuerpo social colonizado unificado.

Palabras clave

Abstract

José Joaquín Bermejo, Cristóbal de Aguilar, Cristóbal de Lozano, and Pedro Díaz are not household names outside of Peru. However, these artists are among the most influential painters in the history of art of the eighteenth-century world. As the premier portrait painters in the global capital of Lima, these artists made visible the identities of powerbrokers who helped to shape the Ibero-American empire in its twilight. Collectively, Bermejo, Aguilar, Lozano, and Díaz facilitated a pictorial shift within a traditional genre that required archaism and repetition to maintain its cultural relevance. Their finished portraits visually demonstrate an emerging dissonance between artistic innovation and pictorial tradition. Through an examination of their late eighteenth-century corpus of work, this article demonstrates how artists adjusted the representation of elite bodies in portraiture to reflect the subtle disintegration of a unified colonized social body.

Keywords Portrait, Lima, tradition, innovation, painting, colonial subjectivity. 
DOI: http://dx.doi.org/10.22201/iie.18703062e.2018.113.2655

\author{
EMILY A. ENGEL
}

\title{
Artistic Invention as Tradition In the Portrait Painting of Late-Colonial Lima
}

$\mathrm{H}$ istorically, the genre of portraiture exists on the precipice of tradition within reach of forward-looking innovative representational strategies. ${ }^{I}$ For generations, art historians have described the genre of portraiture in terms of its ability to visualize the likeness, identity, personality, and emotional state of its subjects. ${ }^{2}$ Undeniably, a portrait refers to an individual in recognizably visual ways; even the most abstract portraits retain enough visual semblance to connect the resulting artwork with the depicted sitter. Harry Berger, however, disrupted this analytical paradigm when he suggested that portraits do not show the sitter objectively, as he or she really is. Berger's thorough analysis of the relationship between portraitists and their sitters demonstrated that the process of creating a portrait nurtured the development of distinct personal identities and inter-personal relationships for the parties involved. ${ }^{3}$ By focusing on a sitter's individual subjectivity, the complex working strategies of portrait artists have often been overshadowed. ${ }^{4}$ Stylistic

I. I would like to thank Derek Burdette, Barbara Mundy, and the anonymous peer reviewers for their insightful feedback on earlier versions of this work.

2. John Berger, The Look of Things (New York: Viking Press, I97I); Richard Brilliant, Portraiture (London: Reaktion Books, 199I), 23-44; Portraiture: Facing the Subject, ed. Joanna Woodall (Manchester and New York: Manchester University Press, 1997); Robert Rosenblum, "Portraiture: Facts versus Fiction," in Citizens and Kings, Portraits in the Age of Revolution, 1760-1830 (London: Royal Academy of Arts, 2007), I4-I5.

3. Harry Berger, "Fictions of the Pose: Facing the Gaze of Early Modern Portraiture," Representations, no. 46 (1994): 87-I20.

4. David Bindman, "Subjectivity and Slavery in Portraiture: From Courtly to Commercial 
and compositional innovations point to the social dimensions of portraits in which artistic dissatisfaction with traditional approaches parallels observable shifts in sociopolitical realities.

In I75I, Pedro Bravo de Lagunas y Castilla, a limeño lawyer living in the capital of the Viceroyalty of Peru, commissioned a local artist to paint his portrait (fig. I) Cristóbal de Lozano (c. 1705-1776), who was the official painter of the viceregal court at the time, created a somber full-length portrait of Bravo de Lagunas that depicted its subject as an educated, working attorney, wearing the proper attire for his vocation and possessing the requisite accessories as demonstrations of his wealth and social status. The books splayed open and stacked on a desk positioned to the side of Bravo de Lagunas, as well as a lengthy inscription at the bottom of the painting, firmly establish the identity of the depicted sitter as an influential American legal professional. Bravo de Lagunas is also framed by a pillar on the left and a voluminous red curtain gathered in the upper-right corner of the canvas suggesting the artist may have drawn inspiration from earlier European portrait traditions.

The form, content, and composition of this formal portrait seem frozen in time, literally underscored by the small arrested watch poised in Bravo de Lagunas' left hand. The primary attributes of the painting — the solemn color palette, the static positioning of objects and sitter, the standard architectural framing, and the boilerplate inscription - are not innovative by any stretch of the art historical imagination, as portraits in the Iberoamerican world had exhibited these qualities for almost two hundred years prior to the creation of this painting. Instead, the portrait is predictable. Lozano paints the portrait with precise attention to well-established pictorial conventions that reinforced its patron's social status during a time of uncertainty and change.

Lima, Peru's viceregal capital, arguably the economic engine of the Spanish Empire and a lynchpin in the global economy during the early modern period, was an epicenter of transnational cultural exchange throughout the colonial period. ${ }^{5}$ Merchants, officials, missionaries, artists, and other enterprising individuals took up residence in the city and its coastal port at Callao to seek their earthly and spiritual fortunes. As an early modern center of power and commerce, Lima

Societies," Agnes Lugo-Ortiz and Angela Rosenthal, in Slave Portraiture in the Atlantic World, (Cambridge: Cambridge University Press, 2013), 75.

5. Alejandra Osorio, Inventing Lima: Baroque Modernity in Peru's South Sea Metropolis (New York: Palgrave MacMillan, 2008), I-34. 
DOI: http://dx.doi.org/10.22201/iie.18703062e.2018.113.2655

ARTISTIC INVENTION AS TRADITION

I. Cristóbal de Lozano, Pedro José Bravo de

Lagunas, I75I, Casa Aliaga, Lima.

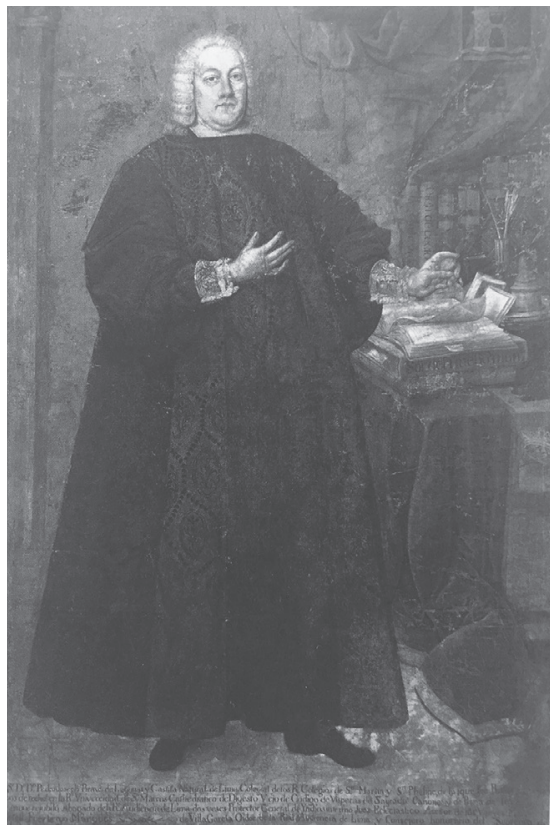

was home to a robust artistic community supported by institutional patrons, wealthy elites, and urban collectives. We are able to document a coherent lineage of artistic production that emerged in mid eighteenth-century Lima. This cohort of painters included Cristóbal Daza (c. 1720), Cristóbal de Lozano, Cristóbal de Aguilar (active 175I-I77I), and José Joaquín Bermejo (c. 1777). Working alongside each other as peers this group of artists collectively expanded the creative potential of the genre of portraiture at the end of the colonial period. Although Daza, Lozano, Aguilar, and Bermejo worked for powerful patrons steeped in Spanish imperial political ideological currents, the portraits they created betray an artistic agency reflected in artistic choices, the elaboration of complex iconographies, and unique compositional matrices producing an artistic tradition that would influence artmaking in Peru for generations.

\section{The Portrait as Site of Innovation}

Portraits were displayed throughout American cities following the Spanish conquest. Royal portraits were feted in public celebrations, mounted on the façade 
of public buildings, and ubiquitous on coins and medals. ${ }^{6}$ Elites amassed collections of family portraits depicting generations of ancestors in paintings displayed along the walls of rooms used to entertain guests. ${ }^{7}$

Portrayal of an individual's likeness in a large-scale oil painting was a way to establish rank in Spanish American social hierarchies that were constantly in flux. Social networks shaped the art of portraiture from the beginning of the Spanish colonial period in the sixteenth century. Over the course of two hundred years, portraiture developed as an art of visual exclusion where only the few were represented, largely in service to personal wealth and power upheld by Spanish imperial domination. By investigating the contexts in which elite portraits were created, it becomes clear that the images were the result of a fruitful collaboration between artists and patrons.

Often found wanting in terms of artistic creativity, portraits produced in late colonial America were once described as second-rate provincial copies based on imported engravings and European prototypes. ${ }^{8}$ American artists throughout the colonial period adjusted, comments Jeanette Peterson, "standard iconographic patterns by adding symbolic paraphernalia or novel interpretations," which art historians continue to trace as they address the genealogy of early modern Latin American artworks. ${ }^{9}$ Reading this interpretation through schemata of invented traditions, Latin American artists appear to have been constrained to working within the limits established by European artists. As a result, the visual objects they produced were interpreted by twentieth-century scholars as conforming to imported conventions.

In response to this interpretive claim, Peruvian art historians have described the repetition of pictorial tradition in the visual arts of colonial South America as archaism. ${ }^{\text {IO }}$ Ricardo Estabridis sees "evidence of an archaizing aesthetic in Spanish Baroque painting created during the second half of the seventeenth

6. Víctor Mínguez, Los reyes solares: iconografía astral de la monarquía hispánica (Castelló de la Plana: Universitat Jaume I, 200I), 209-246.

7. Behind Closed Doors: Art in the Spanish American Home, I492-I898, ed. Richard Aste (New York: Brooklyn Museum, 20I3).

8. Gauvin Bailey, Art of Colonial Latin America (London: Phaidon Press, 2005), 167-206.

9. Jeanette Peterson, "Renaissance: A Kaleidoscopic View from the Spanish Americas," in Renaissance Theory, ed. James Elkins and Robert Williams (New York: Routledge, 2008), 325.

Io. Ricardo Estabridis, "El retrato del siglo XviII en Lima como símbolo de poder", in El barroco peruano, ed. Ramón Mujica Pinilla, 2 vol. (Lima: Banco de Crédito, 2003), I35-I7I. 
century. ${ }^{\text {II }}$ For Estabridis eighteenth-century pictorial innovation is to be found in personal artistic style, boldly contrasting with the dominant baroque period style that he identifies in seventeenth-century limeño painting. ${ }^{12}$ Moreover, Luis Eduardo Wuffarden has explored the archaizing tendency in mid-colonial Peruvian art, calling it "a moment of profound stylistic indecision and fascinating formal experiments, a time in which the various available options coexisted in a constantly evolving mix." 3 Wuffarden summed up the prevailing wisdom regarding late colonial South American portraiture in an essay aptly titled "Enlightenment Versus Local Tradition, I750-I825," in which he suggests that the Spanish Bourbon reform agenda set in motion "a dynamic of progress" in the visual arts culminating in the artistic production of the independence period. ${ }^{14}$ Wuffarden describes a South American artistic florescence stemming from the importation of European enlightenment ideology which local creole artists and patrons emulated at the same time as they "championed a distinct Spanish American identity." I5

Eighteenth-century artistic innovations in the genre of portraiture responded to Lima's contemporary social realities. Political treatises resurrected the virtues of monarchical absolutism celebrated in the sixteenth century when politics mediated the configuration of power throughout the Iberoamerican world. ${ }^{16}$ Increased political instability necessitated a pictorial turn toward archaism to reassert the stability of the past and the predictability of the future. The resulting body of work, series and individual portraits of individ-

II. "Evidencia [de] un gusto arcaizante por la pintura barroca española de la segunda mitad del [siglo XVII]", en Ricardo Estabridis, "El retrato en Lima en el siglo XviII: Las pinturas de Cristóbal Lozano," in Tradición, estilo o escuela en la pintura iberoamericana, siglos XVI-XVIII: Primer seminario de pintura virreinal (Mexico City: Universidad Nacional Autónoma de México-Instituto de Investigaciones Estéticas, 2004), IO4.

I2. Ricardo Estabridis, "Cristóbal Lozano, paradigma de la pintura limeña del siglo XvıII," Actas III Congreso Internacional del Barroco Americano: territorio, arte, espacio y sociedad (Sevilla: Pablo de Olavide, 200I), 298-299.

13. Luis Eduardo Wuffarden, "Between Archaism and Innovation, I610-70," in Painting in Latin America, I550-I820, eds. Luisa Elena Alcalá and Jonathan Brown (New Haven and London: Yale University Press, 20I4), 276.

I4. Luis Eduardo Wuffarden, "Enlightenment Versus Local Tradition, I750-1825," in Painting in Latin America, I550-I820, ed. Luisa Elena Alcalá and Jonathan Brown (New Haven and London: Yale University Press, 2014), 365.

15. Wuffarden, "Enlightenment Versus Local Tradition," 369.

I6. Carlos Morales Cerón, "Teoría política y fundamentos del poder real en el virreinato del Perú (siglos XVI-XIX)," Investigaciones Sociales I4, no. 24 (20I0): I49-I69. 
uals depicted in pioneering ways, was produced in response to the frustration of American artists who were unsatisfied by the inhibited working constraints placed upon them when asked to employ archaic pictorial strategies to "recover, preserve, and showcase the past." ${ }^{\text {"7 }}$ Artists progressively turned to innovative painterly techniques, applied within the context of predictable archaism, to invent new pictorial traditions suitable for depicting the sociopolitical changes swirling around them in the viceregal capitals.

The images produced by this turn toward innovative painterly practice in the viceregal capitals at Mexico City and Lima were deeply embedded in the gradual evolution of pictorial traditions. Painters invented these traditions through their work as portraitists commissioned to create an official American visual culture. Eric Hobsbawm's theorizing of invented traditions focused on the rules, rituals, and behavioral norms that produced recognizable sociocultural practices. Hobsbawm's invented traditions were attempting to "establish continuity with a suitable historic past" that only needed to be relevant, not necessarily lengthy. ${ }^{18}$ In late-colonial Iberoamerica, artists developed new pictorial conventions, such as more complex compositions that complicated illusionistic expectations, highly ornamented surfaces dominated by heavy outlines, and exceptional dynamism. Artists repeated what could be seen as technical painterly conventions, formally reshaping the representational art of portraiture into an artform that could confront local American realities while retaining its connections to two centuries of Iberoamerican colonial history.

Courtly artists, in particular, educated and succeeded each other, forming the first coherent American artistic lineages, which shaped the development of the visual arts for generations. Year-over-year, throughout the late colonial period, skilled painters occupied a privileged position at the pinnacle of viceregal society where they collaborated to develop techniques, compositional strategies, and iconographies in creating inventive portraits to satisfy the demands of their patrons while simultaneously giving visual form to the history of Spanish American colonialism.

17. Wu Hung, "Patterns of Returning to the Ancients in Chinese Art and Visual Culture," in Reinventing the Past: Archaism and Antiquarianism in Chinese Art and Visual Culture, ed. Wu Hung (Chicago: University of Chicago-Department of Art History/Center for the Art of East Asia/Art Media Resources, 20IO), I4.

I8. Eric Hobsbawm, "Introduction: Inventing Traditions," in The Invention of Tradition, ed. Eric Hobsbawm and Terrence Ranger (Cambridge: Cambridge University Press, 1983), 2. 


\section{Portrayal in the Eighteenth-Century Iberoamerican World}

When Philip V ascended the Spanish throne in I700, the Habsburg period came to a close and a new French Bourbon chapter in the history of the Spanish monarchy was inaugurated. Best known as a period of socioeconomic reform, eighteenth-century Bourbon Spain was governed by a spirit of enlightened absolutism. The government of Charles III (I759-I788) legislated far-reaching agricultural, religious, financial, and political changes across the Iberoamerican world. Appointed by Charles III, José de Gálvez became a leader in the official Spanish Bourbon attempts to improve administration, fiscal balance, and military organization. Gálvez served as a royally appointed general inspector in Mexico (1764-I772) and later earned a seat on the Council of the Indies (I775-1787) where his influence shaped imperial policy in the farthest reaches of Spanish America, from California to Alto Peru. In 1776, Gálvez dispatched José de Areche to Latin America as an inspector general tasked with evaluating the current state of affairs in the viceregal capitals and other important locations. Areche was also responsible for implementing changes in the American imperial governmental system. In addition to reconfiguring territorial boundaries, the reforms of 1776 included increasing the alcabala tax to six percent and establishing a customs house at La Paz. These changes destabilized colonial bureaucracies and demanded more efficient extraction of revenue from Spain's American territories. Gálvez endeavored to reestablish Spain's authority within its distant territories. ${ }^{19}$ This attempted re-colonization of the Americas constituted the Spanish response to a perceived up-tick in American autonomy and, in particular, a decrease in viceregal efficacy and loyalty. ${ }^{20}$

Charles IV (I788-I808) put increasing pressure on Spanish America when he authorized comprehensive territorial reorganization. His agents were also

19. Gálvez incorporated enlightened strategies that promoted bureaucratic order and scientific rationality in his style of imperial governance, particularly in Latin America. Traditional strategies and religious precedents were replaced through the implementation of a reform agenda. See The Majesty of Spain: Royal Collections from the Museo del Prado and the Patrimonio Nacional (Jackson: Mississippi Commission for International Cultural Exchange, 200I), 34.

20. Independence movements in France, Haiti, and the United States of America also challenged the idea of colonialism and offered alternatives to monarchial government. The revolutions championed principles such as the right to national self-determination and the right to resist oppressive government. Above all, they delineated and supported individual human liberties, a conceptual commonality that may have influenced later national ideologies in South America (Jaime Rodríguez, The Independence of Spanish America [Cambridge: Cambridge University Press, 1998]). 
responsible for an aggressive resubordination of American regions that were exhibiting particularly volatile behavior, such as the comuneros in New Granada or the highland indigenous rebellions of Alto Peru. Re-colonization efforts were primarily enacted through military and economic measures; however, Spanish Bourbon agents in Spanish America also dictated cultural reforms in which theater, music, and the visual arts were thought to be ideal means by which to shape the behavior and loyalty of American subjects. ${ }^{21}$ Spanish Bourbon governors regularly deployed paintings as propagandistic demonstrations.

During this period of mounting secularization, the Spanish monarchy attempted to regain control over artistic production so that the state would serve as the representative of its enlightened territories. In 1777 and I79I, the crown issued restrictions on the arts which particularly addressed recent innovations in religious art. ${ }^{22}$ Such decrees indicate the social significance of local American artistic innovation and its potential threat to Spanish colonial domination in the Americas. In the eighteenth century, the acts of commissioning and displaying painted works of art assumed a primarily secular function that resulted from enhanced local social cohesion. ${ }^{23}$ The material record culture, combined with public display of royal portraits, the circulation of coins and medals, and private collections of visual and verbal portraits, suggests that individuals from a variety of socio-economic backgrounds were conscious of the political implications of not only possessing, but commissioning and displaying a portrait image.

The reserved aesthetic that shaped the development of a Habsburg visual culture throughout the Iberoamerican world slowly began to give way to a spirit of artistic innovation. ${ }^{24}$ The American viceregal capitals were home to vibrant artistic cultures that supported local artists, some of whom emigrated

2I. Juan Pedro Viqueira Albán, Propriety and Permissiveness in Bourbon Mexico, trans. Sonya Lipsett-Rivera and Sergio Rivera Ayala (Lanham: SR Books, 2004), 84.

22. Martha Barriga Tello, Influencia de la Ilustración borbónica en el arte limeño: siglo XVIII (antecedentes y aplicación) (Lima: Fondo Editorial Universidad Nacional Mayor de San Marcos, 2004), 70.

23. Although portraiture increased in importance and visibility during the eighteenth century, religious art continued to dominate visual culture with church renovations, sponsorship of ephemeral objects for ritual practice, and devotional imagery. See Luisa Elena Alcalá, Jaime Cuadriello, Ilona Katzew, and Paula Mues Orts, "Painted in Mexico, I700-1790," in Painted in Mexico, I700-I790: Pinxit Mexici, ed. Ilona Katzew (Los Angeles: Los Angeles County Museum of Art, 2017), I6-5I.

24. Leticia Ruiz Gómez, "Court Portraits in the Spanish Monarchy (I530-I660)," in The 
to the city, operated successful workshops, and trained accomplished students who began to establish visual legacies in the eighteenth century. An increase in the number of working artists and the demand for portraits led to a marked uptick in the number of Iberoamerican portraits produced during the Bourbon reform period. ${ }^{25}$ As a traditional art of power, portrait painting and collecting became more widespread.

Throughout the eighteenth century, the imperial and viceregal courts persisted as influential patrons of the arts by hosting court painters, sponsoring performances, and founding arts academies. For over 150 years, Spanish monarchs had entrusted their American viceroys with the responsibility of representing the power of the distant Spanish monarchy and efficiently administering colonial governments. Juan de Matienzo described the viceroy as the "head of the body politic" in his 1567 treatise on the early colonial government of Peru. ${ }^{26}$ Seen as the "king's living image," viceroys were not only political figureheads; from their position at the pinnacle of viceregal society, viceroys shaped the urban environments where they resided. ${ }^{27}$ Their policies touched all aspects of life in the American viceregal capitals, from public health to cultural advancement. By the turn of the eighteenth century, the viceroys of Mexico and Peru had become indispensable patrons of the arts in Spanish America.

The first Bourbon viceroy of Peru, Manuel de Oms (r. 1707-I710), was appointed to lead the South American viceroyalty by Philip V as a reward for his service and loyalty during the War of Spanish Succession which brought Philip V to the throne as the first Spanish Bourbon. Oms, a Catalonian noble, had been assigned as the Spanish ambassador to the Parisian court of Louis XIV in $\mathrm{I} 698$. During his time at the French court, Oms developed an affinity for all things French and became a cultured diplomat, collecting art, composing music, and writing plays. When he arrived in Lima three years after Philip V awarded him viceregal distinction, Oms brought his art collection, musicians, and a library which became influential in the viceregal capital almost immediately.

Spanish Portrait, From El Greco to Picasso, ed. Javier Portús (Madrid: Museo Nacional del Prado, 2004), 92-109.

25. Inmaculada Rodríguez Moya, "El retrato de la élite en Iberoamerica siglos XVI a XVIII," Tiempos de América, no. 8 (2001): 79-92.

26. Juan de Matienzo, Gobierno del Perú (Buenos Aires: Compañía Sud-Americana de Billetes de Banco, I9Io [1567]).

27. Alejandro Cañeque, The King's Living Image, The Culture and Politics of Viceregal Power in Colonial Mexico (New York and London: Routledge, 2004). 
Oms' art collection included two well-regarded portraits by the French court painter Charles Le Brun, a portrait of Louis XIV and his heir Louis, Grand Dauphin (both now lost) painted before $1690 .{ }^{28}$ As ambassador to the court of Louis XIV, Oms was familiar with Le Brun's position as first painter to the king in the royal court. Le Brun's close relationship with Louis XIV imbued the artist with wealth and far-reaching influence in the cultural affairs of seventeenth-century France and beyond. Although Oms did not appoint a court painter with the notoriety and power of Le Brun, the Francophile viceroy publicly sponsored the arts throughout his short tenure in office. According to the nineteenth-century viceregal biographer José Antonio Lavalle, Oms organized

literary gatherings and parties; the French affability of the viceroy and the customs and fashions of the royal court at Versailles, where he had lived for many years and introduced into Lima, contrasted with the severity and austerity of limeño life, its fashions and modes of dress as dominated by the viceroys during the Habsburg period. Critics of this approach attacked the viceroy and made him the target of criticism and satire, with the goal of diminishing the viceroy's dignity and even degrading the viceregal palace, which he had converted into an academy and a theater. ${ }^{29}$

Within this atmosphere of reform, sociocultural enlightenment, and innovation, art historians would expect to find portraits influenced by the opulent painterly style of the seventeenth-century French court, like Le Brun's brooding portrait of Louis XIV which combined loose softness with nuanced modeling to create an intimate yet noble likeness (fig. 2). On the contrary, early eighteenth-century Iberoamerican portraits tended toward the archaic reinterpretation of local seventeenth-century pictorial practices.

28. Núria Sala i Vila, "La escenificación del poder: El Marqués de Casteldosrius, Primer Virrey Borbón del Perú, I707-I7Io," Anuario de Estudios Americanos, no. 6I.I (2004): 3I-68.

29. "Reuniones y fiestas literarias; la sociabilidad francesa del Virrey y las maneras y modas de la corte de Versalles, en que había residido tanto tiempo y que pretendía introducir en Lima, contrastaban de tal manera con la severidad y aun austeridad de vida, costumbres y trajes de los virreyes del tiempo de la casa de Austria, que chocaron extraordinariamente en Lima é hicieron blanco al Virrey de la crítica y aun de la sátira, pretendiendo que amenguaba su dignidad y aun degradaba el palacio virreinal, convirtiéndolo en academia y en teatro.” José Antonio Lavalle, Galería de retratos de los gobernadores y virreyes del Perú (1532-1824) (Lima: Domingo de Vivero, "Librería Clásica y Científica", I89i), 56. 
DOI: http://dx.doi.org/10.22201/iie.18703062e.2018.113.2655

ARTISTIC INVENTION AS TRADITION

2. Charles Le Brun, Louis XIV, ca. I665, pastel on gray paper, $51.5 \times 39.8 \mathrm{~cm}$. Photo: JeanGilles Berizzi. Musée du Louvre c RMNGrand Palais/Art Resource, NY, INV29874.

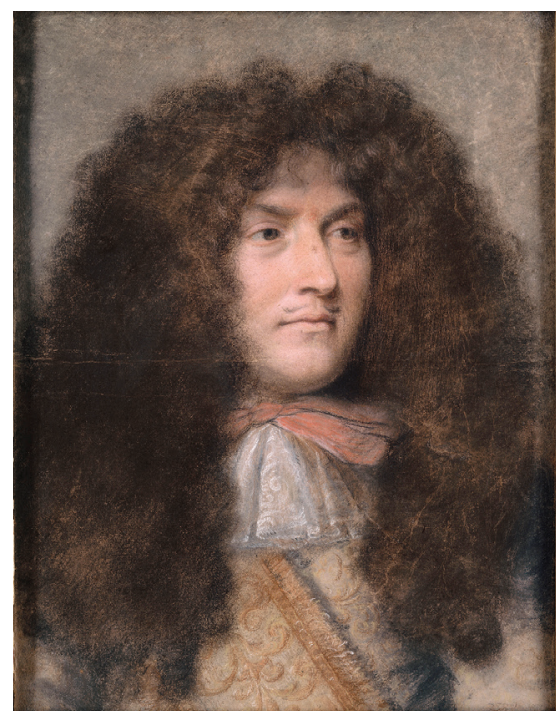

\section{Mexican and Peruvian Viceroy Paintings}

Bravo de Lagunas and Oms were not the first Spanish American art collectors to amass treasured paintings for personal diversion. Earlier generations of American art collectors had imported artworks from abroad and commissioned local artists to create works to adorn their homes and institutions. George Kubler first identified Mexico City and Lima, along with Havana, Bogotá, Quito, and Rio de Janeiro, as "metropolitan centers" which were also the primary centers of artistic production in the viceregal period. ${ }^{30}$ In Kubler's telling, Mexico City and Lima were not just centers of government and trade, they were centers of urban cultural production that were influential in their own right.

It should come as no surprise then, that Mexico City and Lima were among the first cities in the Iberoamerican world to host series of official portrait paintings. Some of the most important local institutions in Mexico City and Lima began collecting and displaying official portraits in the early seventeenth cen-

30. George Kubler, "Metropolitan Schools in Latin American Archaeology and Colonial Art," in Latin American Art, and the Baroque Period in Europe (Studies in Western Art: Acts of the Twentieth International Congress of the History of Art), ed. Millard Meiss, vol. 3 (Princeton: Princeton University Press, 1963), I45-I47. 
tury. ${ }^{3 \mathrm{I}}$ By the middle of the century, university, convent, and municipal halls were lined with series of official portraits documenting the histories of American institutions. These portraits, while specific in their iconographies and details, typify early Spanish Habsburg bureaucratic norms, which dictated austerity, formality, and predictability.

A I 666 account describes the display of viceregal portraits in the sala de real acuerdo [formal governing assembly hall] in the viceregal palace of Mexico City:

High on the wall, hanging from a beam are twenty-four, half-length portraits of the viceroys that New Spain has had, from the very famous hero Hernan Cortés, her conqueror and first governor, although without title of viceroy, to the Marques de Mancera, who today governs her. ${ }^{32}$

Omitted from this account is a detailed description of the portrait paintings themselves; the author, rather, focuses his attention on the historical content of the portraits, in particular the identities of the sitters. However, this series, and another viceroy portrait series which was displayed in the cabildo (municipal council chamber) as a compliment to the courtly collection, have been preserved until the present day. ${ }^{33}$ In both series, the seventeenth-century portraits demonstrate a painterly attention to early Habsburg royal portrait models. For example, the mid seventeenth-century portrait of Viceroy Luis Enríquez de Guzmán (r. 1650-1653) shows the sitter statically posed against a muted gray backdrop (fig. 3). The unidentified artist has naturalistically painted Viceroy Guzmán's likeness from the folds of skin rippling against each other on his neck to his squarely cut hair spilling down on top of the formal collar of his suit. The large field of black that makes up Viceroy Guzmán's costume is punctuated by gold ornaments hanging from his neck and waist. The half-length figure is turned toward the viewer; however, his eyes shift to the edge of the

3I. Inmaculada Rodríguez Moya, La mirada del virrey, iconografía del poder en la Nueva España (Barcelona: Universitat Jaume I, 2003); Emily Engel, "Official Portraiture and Authority in LateColonial Lima and Buenos Aires," Dieciocho 33, no. I (2010): 169-206.

32. "Llanto del occidente," by Isidro Sariñana from I666 (fol. I4r) cited in Michael Schreffler, The Art of Allegiance, Visual Culture and Imperial Power in Baroque New Spain (University Park: The Pennsylvania State University Press, 2007), 72.

33. Rodríguez describes three series of viceroy portraits in New Spain: the cabildo, the palace, and the art academy (Rodríguez Moya, La mirada del virrey, 95). 
3. Unidentified artist, Luis Enriquez de Guzmán, c. 1650, $93 \times 67$ cm, Museo Nacional de Historia. Secretaría de Cultura-INAH-Méx.

"Reproducción autorizada por el Instituto Nacional de Antropología e Historia”.

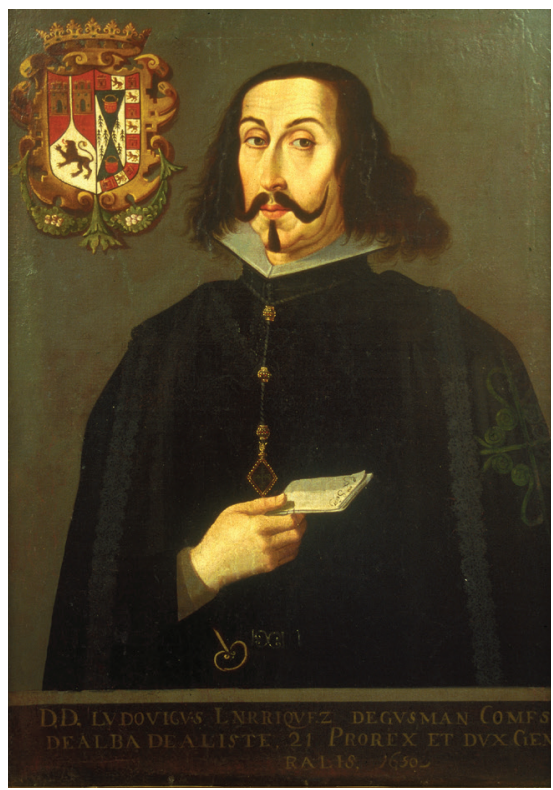

picture plane without directly engaging with the audience outside the image. A formal inscription and exquisitely detailed coat of arms securely establish the identity of Viceroy Guzmán in both contemporary and historical terms. The portrait's closely cropped composition provides the viewer with little else to explore visually.

The minimalism, order, and continuity observed in the seventeenth-century viceroy portraits in the Mexican series were directly inspired by the portraits of the first Spanish Habsburg monarchs. Portraits of Charles V and Philip II exhibit the highly-selective simplicity and elegant restraint that characterized their reigns (fig. 4). Far from austere, the early Spanish Habsburgs favored an imposing yet controlled aesthetic deployed across large-scale installations, like Philip II's Escorial project. ${ }^{34}$ Rosemarie Mulcahy has observed that court portraiture in Spain at this time promoted the power and prestige of the ruler, projected territorial control, and emphasized royal legitimacy and succession. ${ }^{35}$

34. Henry Kamen, The Escorial: Art and Power in the Renaissance (New Haven and London: Yale University Press, 2010).

35. Rosemarie Mulcahy, Philip II of Spain: Patron of the Arts (Dublin: Four Courts Press, 2004). 


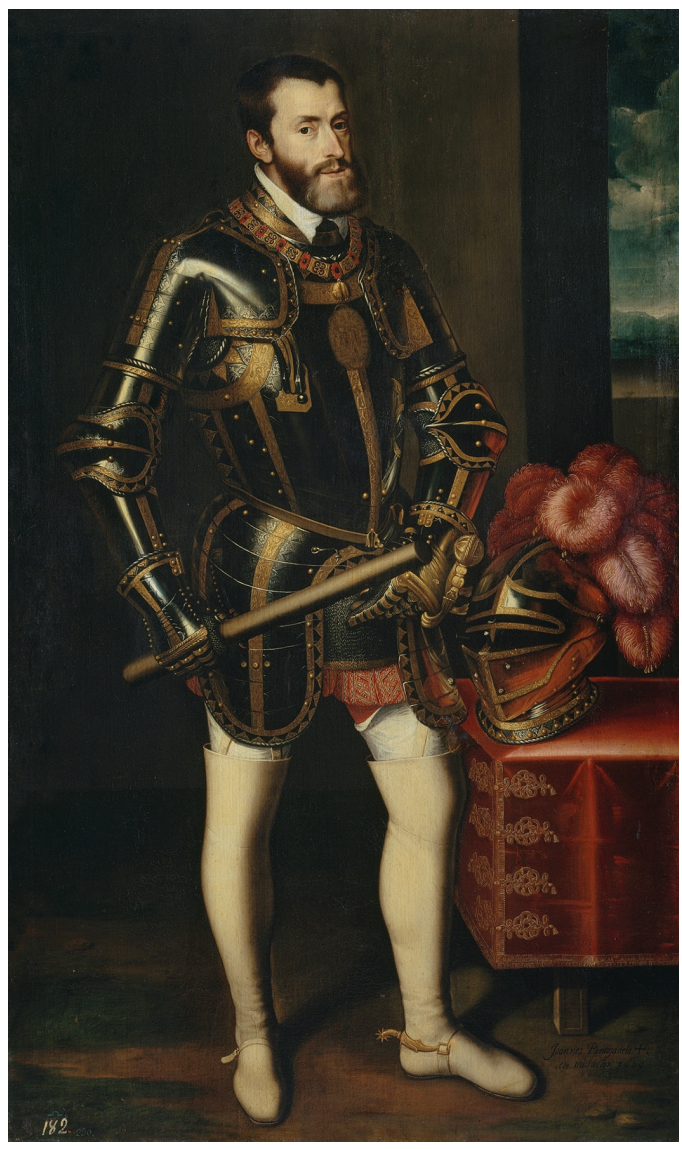

4. Juan Pantoja de la Cruz, Charles $V$, I605, oil on canvas, I $83 \times$ IIo cm, Museo del Prado, Madrid.

The simplicity of early Spanish Habsburg portraiture was perfectly suited for rendering the illusion of the physically present viceroy, governing in the spirit of distant monarchs year after year. ${ }^{36}$

36. Michael Schreffler has observed that "the portraits of Kings and Viceroys in the Hall of Royal Accord in the Royal Palace gave visible and material form to a mode of governance from afar in the empire of the Spanish Habsburgs." (Schreffler, The Art of Allegiance, 8I). See also Víctor Mínguez, Los reyes distantes. Imágenes del poder en Mexico virreinal (Castelló: Universitat Jaume I, 1995); Víctor Mínguez, "Leo Fortis, Rex Fortis. El leon y la monarquía hispánica," in El imperio sublevado: monarquía y naciones en España e Hispanoamérica, ed. Víctor Mínguez and Manuel Chust (Madrid: Consejo Superior de Investigaciones Científicas, 2004), 57-94. 
DOI: http://dx.doi.org/10.22201/iie.18703062e.2018.113.2655

ARTISTIC INVENTION AS TRADITION

5. Unidentified artist, Luis Enríquez de

Guzmán, ca. 1650, oil on canvas. Museo Nacional de Arqueología, Antropología e Historia del Perú, Lima.

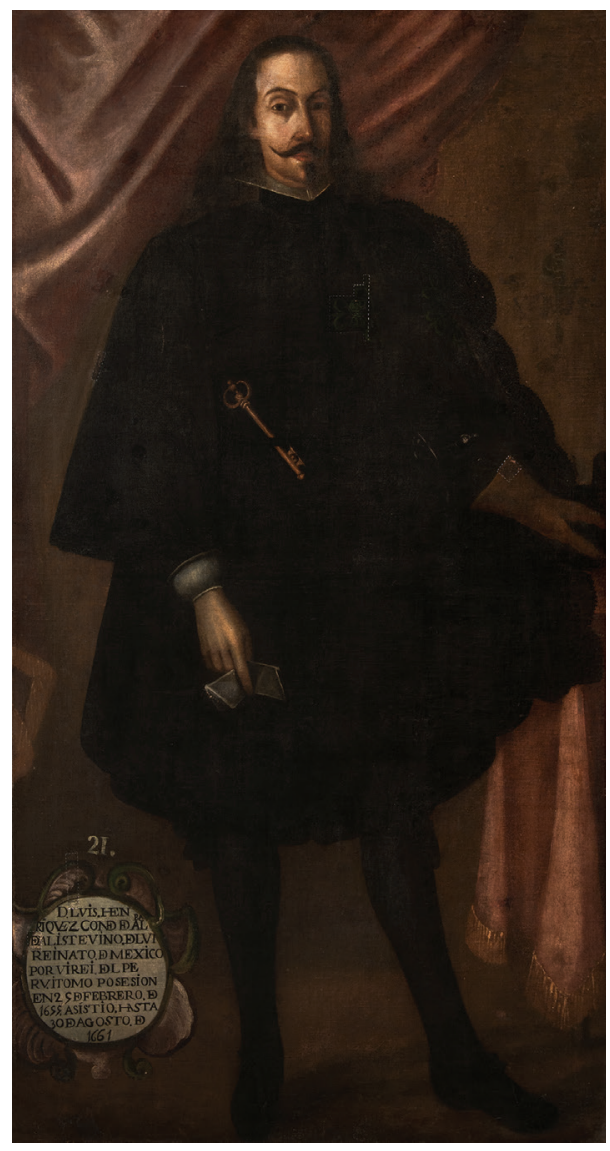

The artists of the Peruvian viceroy paintings also framed their contemporary sitters using visual precedents established during the reigns of Charles $\mathrm{V}$ and Philip II. After serving as viceroy of New Spain, Luis Enríquez de Guzmán was assigned to lead the Viceroyalty of Peru. During Viceroy Guzmán's tenure in Lima (r. 1655-I66I), his portrait was painted on at least one occasion. The Guzmán portrait remains part of the former municipal council series exhibited today in the Museo Nacional de Antropología, Arqueología e Historia del Perú (fig. 5). This portrait, following its predecessors in the municipal portrait series, is uniform in physical canvas size. The unidentified artist filled the composition with the full-length figure of the viceroy standing in a shallow space 
framed by a checked-tile floor, velvet curtain, and inscribed cartouche. Viceroy Guzmán wears a black hat, coat, cape, and breeches, a shirt with ruffled white sleeves and collar, and stockings. The red cross of the Order of Santiago is painted on the shoulder of his cape, indicating his membership in the exclusive honorary order. All of the attributes of Viceroy Guzmán's attire parallel his portraits in the Mexican viceroy portrait series. Viceroy Guzmán's likeness is one of the few unique attributes of the painting. The unidentified artist who painted Viceroy Guzmán's portrait skillfully captures the sitter's likeness, including his facial hair, pointed nose, and penetrating gaze, which also captivated the Mexican artists who painted his portrait several years earlier.

In the absence of iconographic complexity, the viewer is left to contemplate the viceroy's physical appearance, his biography, and his place within the chronology of viceregal governance. Like the Mexican viceroy portrait series, the Lima viceroy portraits document the passage of time in colonial terms. The history of each viceroyalty is delimited by the individual tenures of viceroys, whose accomplishments while in office give form to distinct episodes in a coherent linear historical narrative. Sixteenth- and seventeenth-century portrait paintings attempted to safeguard colonial elite privilege over time through visual conventions, limited innovation, and predictability. However, the Bourbon ascendency and resulting imperial restructuring destabilized the context in which elite portraits operated. The model of imperial elite privilege previously indexed by the portraits collected by individuals and institutions came under rising scrutiny in the wake of internal viceregal instability and external attacks. ${ }^{37}$ Viewers of portraits from across the social spectrum grew more and more critical of Spanish imperial governance as exploitation reappeared in new, more aggressive forms and economic growth faltered throughout the Iberoamerican world. The reception of portraits could not be sanitized or controlled; viewers brought awareness of social fractures, economic burdens, and social fragmentation to their visual experiences with portraiture.

The municipal council and viceregal chambers that displayed viceregal portraits were the primary centers of governance in viceregal Latin America. Colonial subjects of all backgrounds frequented the viceregal court, municipal council, and other colonial institutions in Lima and Mexico City where officials from the viceroy on down were required to patiently interact with

37. Karen Spaulding, Huarochiri: An Andean Society Under Inca and Spanish Rule (Palo Alto: Stanford University Press, 1984), 270-293. 
concerned subjects..$^{38}$ Michael Schreffler has suggested that groups of portraits like those of the viceroys of New Spain were used by the Spanish monarchy to manage the government of the viceroyalty, a function which had a great significance in the early decades of Spanish domination across the Americas but which diminished in the eighteenth century when imperial relations were forcefully reformulated. ${ }^{39}$ Whereas the viceregal portrait series displayed in the seventeenth century helped to cement absent Spanish absolutist monarchical rule in the Iberoamerican world, the production and display of portraits assumed culturally specific purposes during the eighteenth century. As Inmaculada Rodríguez has shown, viceroy portraits were representations of power that were created against the sociocultural backdrop of political change throughout the viceregal period..$^{\circ}$ By the close of the eighteenth century, portraits like the viceroy series became active participants in the sociopolitical transformations that precipitated independence and nation building throughout Latin America. ${ }^{4 \mathrm{I}}$

The historic viceroy portraits and each newly commissioned painting added to the series over time began to embody a sense of artistic innovation eschewed by previous generations of viceregal painters. The portraits painted by late-colonial artists perpetuated elements of traditional Habsburg portraiture imbuing their works with a sense of historicity that was counterbalanced by the contemporary nature of the paintings' iconographic content. When we consider the development of artistic practice across the Iberoamerican world, it becomes apparent that the expectations of history shaped (through expansion and contraction) the artistic process to varying degrees based on geographic location and historical context. Our understanding of viceregal portraiture in colonial Latin America traces "geographies of art that establish dialogues of correspondence and counterpoints between different latitudes of the Hispanic monarchy." 42 By the eighteenth century, the practices of art production and collecting diverged in the Viceroyalties of New Spain and Peru. Collectors in

38. Morales Cerón, “Teoría política y fundamentos del poder," I6I; George Juan and Antonio de Ulloa, A Voyage to South America (London: John Stockdale, I807).

39. Schreffler, The Art of Allegiance, 95-IO4.

40. Rodríguez Moya, La mirada del virrey.

4I. Tomás Pérez and Marta Quezada, De novohispanos a mexicanos: retratos e identidad colectiva en una sociedad en transición (Mexico City: Instituto Nacional de Antropología e Historia, 2009).

42. Thomas Dacosta Kaufmann, Toward a Geography of Art (Chicago: University of Chicago Press, 2004), 272-299. 
DOI: http://dx.doi.org/10.22201/iie.18703062e.2018.113.2655

60

EMILY A. ENGEL

Lima began to privilege locally produced artworks as "products of the land that distinguished Peru from other regions within the Spanish Empire."43

\section{Artistic Lineages}

Pedro José Bravo de Lagunas was a successful limeño attorney, a former member of Lima's high court, and a member of the Council of the Indies; however, in the 1760 s, he retired from public life into the monastic vocation. Bequeathing his earthly wealth to family members and religious groups, Bravo de Lagunas revised his last will and testament on December 29, 1765. This unique document provides a detailed description of his fine and decorative art collection, personal library, and sundry other valuables. ${ }^{44}$ Antonio Holguera Cabrera has interpreted Bravo de Lagunas' will as evidence that the limeño attorney was an enlightened collector who had the eye of a trained connoisseur and took great pleasure in his art collection, which also served to reinforce his social position locally and abroad. ${ }^{45}$ Bravo de Lagunas' last will and testament also provides an exceptional look into the local production of art in mid eighteenth-century Lima.

At some point following Oms' death on April 24, I710, Bravo de Lagunas acquired the French royal portraits that had been part of the late viceroy's art collection. Bravo de Lagunas also collected Spanish, Flemish, Italian, and other French paintings, but the majority of the IOS artworks in his collection were created by local limeño artists. Twenty-three paintings were labeled as the work of Cristóbal de Lozano along with twenty-nine paintings by Cristóbal Daza, the largest body of works by a single artist in the collection. Most of the paintings by Lozano were labeled as portraits, such "D. Mauro de Mendoza" and "Marqués de Villagarcía", while others depict type figures like "un pobre" or "mudo." ${ }^{6}$ One painting of the biblical hero David is credited to Lozano.

43. Luis Eduardo Wuffarden, "From Apprentices to 'Famous Brushes': Native Artists in Colonial Peru," in Contested Visions in the Spanish Colonial World, ed. Ilona Katzew (Los Angeles: Los Angeles County Museum of Art, 20II), 267.

44. AGn Perú, "Protocolos Notariales de Lima", "Protocolos de Orencio de Azcarrunz", no. 83, I2.29.I755, folios 477-480.

45. Antonio Holguera Cabrera, "Un coleccionista criollo en la Lima del siglo xvıII: Pedro José Bravo de Lagunas (1703-1765)”, Laboratorio de Arte, no. 29 (2017): 503-524; 5II.

46. AGN Perú, "Protocolos Notariales de Lima", "Protocolos de Orencio de Azcarrunz", no. 83, I2.29.I755, fs. 477-480. 
It was described by the notary Orencio de Azcarrunz in the following terms, "una copia de mano de Lozano y un original de Daza." 47 In this telling example, Lozano emulates his predecessor, Daza, who was a favorite of Lozano's patron, Bravo de Lagunas.

Drawing on the context provided by the description of Bravo de Lagunas' art collection, we start to see the beginning of a coherent artistic lineage localized in the Peruvian viceregal capital. Daza and Lozano were linked together in a professional relationship characterized by emulation and innovation nurtured under the patronage of an elite limeño art connoisseur. Orencio de Azcarrunz provides an unusual amount of descriptive detail in his notarial record of Bravo de Lagunas' art collection. Lima artists were named as the specific creators of artworks in the same context as well-known historical European artists. While many earlier and contemporary wills record the existence of artworks in private collections, there is little evidence detailing the working relationships of specifically identified artists with each other and their patrons. Bravo de Lagunas, Daza, and Lozano appear as the beginning of a collaborative network that fostered the development of portraiture in the late-colonial period.

Lozano's practice of observing local and international artistic precedents, particularly in the works made available to him by Bravo de Lagunas, established a network of creative relationships that continued to grow throughout the eighteenth century. Lozano's tendency toward archaizing in the midst of painterly innovation created a sense of historical stability in his works of art that counter-balanced the instability of the Bourbon reform period. One of Lozano's peers, Cristóbal de Aguilar, adopted compositional innovations in his portraiture, although with a very different result. One of Lima's most successful intellectuals, Pedro de Peralta Barnuevo Rocha y Benavides sat for a portrait by Aguilar which was completed in 175I (fig. 6). Aguilar's portrait of Peralta is visually dominated by a severe style of draftsmanship, somber range of color, and heavy-handed outline. When compared with Lozano's portrait of Bravo de Lagunas completed in the same year, Aguilar tends toward the literal in his likeness of Peralta, whose face reads as a topographical map. In contrast to Aguilar's sharp linearity, Lozano's more pictorial approach is achieved with a softer line and vibrant palette. ${ }^{8}$ Lozano and Aguilar both emphasize

47. agn Perú, "Protocolos Notariales de Lima", "Protocolos de Orencio de Azcarrunz", no. 83, I2.29.I755, fs. 477-480.

48. Ricardo Estabridis, “Cristóbal de Aguilar Casaverde, retratista limeño de siglo XviII," Illapa 


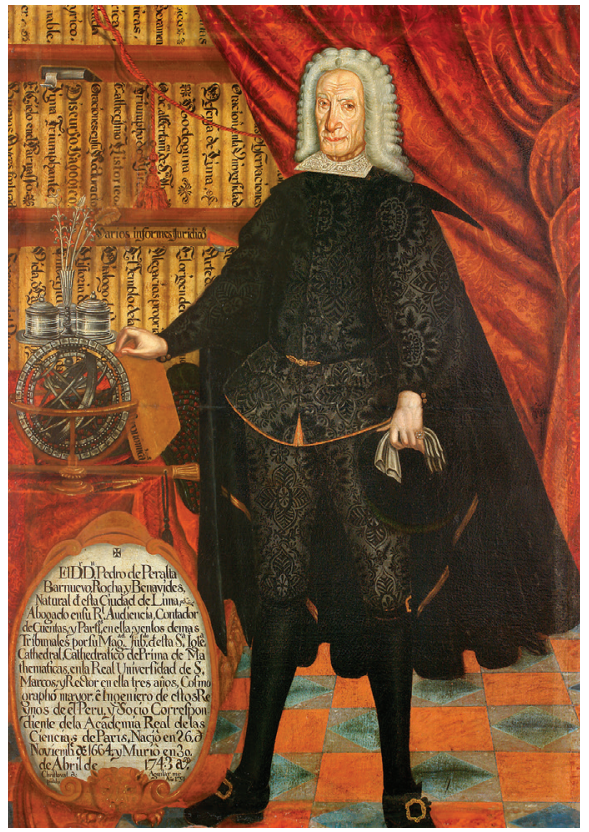

6. Cristóbal de Aguilar, Pedro de Peralta Barnuevo Rocha y Benavides, I75I, oil on canvas, $165 \times 123 \mathrm{~cm}$, Museo de Arte Universidad Nacional Mayor de San Marcos, Lima.

the status of their patrons by creatively deploying baroque ornamentation, lavishly detailed clothing and interiors, and complicated compositional spaces.

Aguilar's style was particularly suited to creating this portrait of Peralta which was commissioned for the Universidad de San Marcos paintings collection. ${ }^{49}$ The University maintained a collection of portraits featuring former directors and notable faculty. Peralta, who published the epic poem Lima fundada in 1732, was a limeño historian who participated in the literary salons organized by Viceroy Oms. ${ }^{50}$ Lima fundada, as well as his earlier Historia de España vindicada from I730, celebrated the history of colonial power in the Viceroyalty of Peru. ${ }^{\text {SI }}$ Peralta envisioned the history of the conquest and colonization of South America in a series of episodes demarcated by the biographies of the

I.I (2004), 30-35.

49. Retratos, Siglos XVI-XX, Museo de Arte Universidad Nacional Mayor de San Marcos (Lima: Museo de Arte del Centro Cultural de San Marcos, 2009), 86-87.

50. Pedro de Peralta y Barnuevo, Lima fundada, o Conquista del Perú (Lima: Francisco Sobrino y Bados, 1732).

51. Pedro de Peralta y Barnuevo, Historia de España vindicada (Lima: Francisco Sobrino y Bados, I730). 
Spanish kings and their viceregal agents. Peralta's lyric virtuosity positions this coherent linear history of the Viceroyalty of Peru as the foundation for eighteenth-century creole intellectualism nurtured by the city of Lima and its institutions like the university.

The Universidad de San Marcos illustrated its own early modern history through a series of portraits collected from the sixteenth century onward..$^{2}$ The portraits documented the history of the institution through a succession of interrelated images collected into a coherent series over the course of two centuries. The San Marcos portraits resembled each other stylistically, iconographically, and compositionally. ${ }^{53}$ Aguilar's portrait of Peralta, for example, follows almost two hundred years of artistic precedent by depicting the fulllength figure of the subject standing in a shallow interior space beside a desk ornamented with books, pens, and other devices. The subject of the portrait is precisely identified by a coat of arms in the upper half of the canvas and an inscribed cartouche in the lower half. Within this pictorial formula, artists freely improvised improvements, ornamentation, and arrangement. The resulting artworks resembled each other, visualizing a coherent institutional legacy for the university. Furthermore, the portraits demonstrated awareness of contemporary stylistic developments, unique content, and artistic innovations.

During the years following Aguilar's portrait of Peralta, the Universidad de San Marcos continued to commission, collect, and display institutional portraits. In 1778, José Joaquín Bermejo created a posthumous portrait of Pedro José Bravo de Lagunas for the university portrait collection (fig. 7). At first glance, this portrait may appear to conform to established portrait conventions; however, in this painting, Bermejo reinterprets the portrait Lozano painted of Bravo de Lagunas over twenty years earlier. Bermejo borrows the figural placement, position, costume, and ornamentation from his predecessor. He depicts the full-length figure of Bravo de Lagunas standing in the dimly lit interior of his study. A curling red curtain, desk, coat of arms, and inscription align with the visual expectations of the university portrait collection. Like Peralta in the earlier portrait by Aguilar, Bravo de Lagunas stands against the backdrop of his personal library in a departure from Lozano's 175 I portrait.

52. Pedro Guibovich, El edificio de letras: jesuitas, educación y sociedad en el Perú colonial (Lima: Universidad del Pacífico, 20I4).

53. Retratos, Siglos XVI-XX (Museo de Arte Universidad Nacional Mayor de San Marcos), 50-IO9. 
DOI: http://dx.doi.org/10.22201/iie.18703062e.2018.113.2655

64

EMILY A. ENGEL

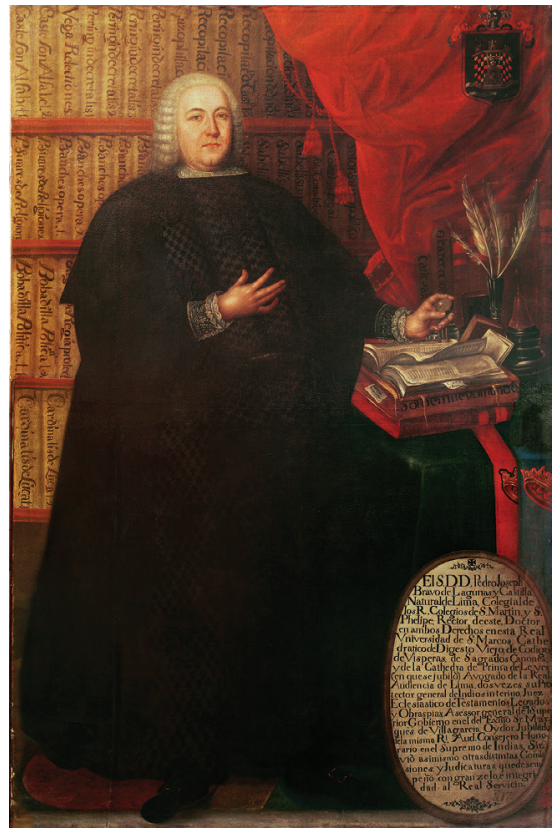

7. José Joaquín Bermejo, Pedro José Bravo de Lagunas, 1778 , oil on canvas, $200 \times 128.5 \mathrm{~cm}$, Museo de Arte Universidad Nacional Mayor de San Marcos, Lima.

Although Bermejo's painting conforms to established official portrait conventions, the next-generation artist enhances the traditional format with innovative visual flourishes. Bermejo breaks down compositional standards when he subtly alludes to the dynamism of the world outside the compositional space of the professor's study. A breeze ruffles the pages of an open book on the desk at Bravo de Lagunas' left and gives life to a cluster of quill pens in a nearby silver cup. The earlier portraits in the collection depict the male subject with one hand upon a closed book statically positioned on the desk, with one exception. Bermejo's predecessor, Cristóbal de Lozano painted a portrait of Martín de Andrés Pérez in 177I for the university collection (fig. 8). This soft portrait not only exhibits Lozano's expert ability to portray his sitter's likeness; the Pérez portrait demonstrates the artist's mastery of pictorial illusionism, color variation, and ornamentation. Lozano depicts Pérez standing before a table, his downcast gaze landing on the verses of an open book. Lozano surrounds Pérez with illusionistic tropes from the labyrinthine architectural matrix at left to the curling corners of a devotional print tacked up on a bookshelf representing the sitter's library on the opposite side of the canvas. Bermejo animates his predecessor's illusionism, bringing the canvas to life. 
8. Cristóbal de Lozano (atributed), Martín de Andrés Pérez, I771, oil on canvas, $167 \times \mathrm{I} 24 \mathrm{~cm}$, Museo de Arte Universidad Nacional Mayor de San Marcos, Lima.

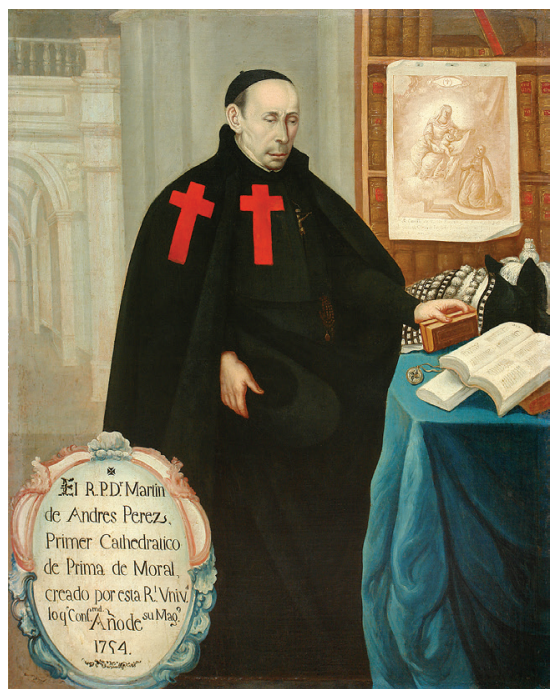

Bermejo continues his use of the circulating current of air into the draped red velvet curtain at the upper right by contorting the billowing fabric and unsettling the tassels near Bravo de Lagunas' upper body. This active representation of seemingly static, frozen objects adds a previously unseen dimension to institutional portraiture. Bermejo's animated illusionism energetically challenges the traditional boundaries of institutional portraiture by bringing the outside world into the pictorial composition to a previously unseen degree. The current of air ruffling the pages, disrupting the pen quills, and puffing up the curtain breaks the proverbial fourth wall. Bermejo places the viewer in the same pictorial space as the depicted sitter, unsettling the historical balance of power upheld by the traditional conventions of portraiture.

Bermejo's reenvisioning of Lozano's earlier portrait of Bravo de Lagunas also exhibits a high degree of specificity. Bermejo emphasizes the representation of extraneous details in the portrait. He creates a selective portrait of Bravo de Laguna's personal library, more than fifteen key works known to have been in the sitter's library are legibly rendered in the portrait, including Voto consultivo, published by Bravo de Lagunas in 1755.54 The precise representation of the volumes that comprised Bravo de Lagunas' library visualizes the tempo-

54. AGN Perú, "Protocolos Notariales de Lima", "Protocolos de Orencio de Azcarrunz", no. 83, I2.29.I755, fs. 477-48o. 
ral movement of history. In its painted form, the limeño intellectual's library encapsulates the worldly epistemological landscape that extends beyond the walls of his study.

In Voto consultivo, Bravo de Lagunas proposed that imperial policies should foremost benefit the "bien común" or "pública utilidad". 55 In the context of a heated public debate surrounding the importation of Chilean grains into the Peruvian territories, Bravo de Lagunas argued that commercial regulation should support the public good. This proposal was derived from the second wave of scholasticism that spawned a revival of traditional ideology throughout the eighteenth century. ${ }^{56}$ As a creole intellectual, born and working in Lima, Bravo de Lagunas grounded his ideas in Iberoamerican traditions, but was not limited by the constraints of sixteenth- and seventeenthcentury absolutist dogma derived from the Siete partidas of Alfonso X. Bravo de Lagunas was part of a growing cohort of political theorists who insisted that the monarchy support the populace it purported to govern. ${ }^{57}$ Bravo de Lagunas, in his political thought and art collecting, respected the value traditional models can bring to the process of finding solutions for contemporary problems. However, Bravo de Lagunas used his reflection on traditional approaches to inform a modern political ideology focused on the collective good, an approach that mirrored the artistic processes of the artists commissionated to paint his portrait. ${ }^{58}$

Art was not separate from the pursuit of the common good in enlightened Spanish thought of the time.59 In the second half of the eighteenth century, Charles IV appointed Antonio Pons to curate the royal portrait galleries, decorate the royal residences, and conduct research in the libraries of the Escorial. Pons discovered and published a sixteenth-century treatise on painting written by Felipe de Guevara, Comentario de la pintura y pintores antiguos. Pons's

55. Pedro José Bravo de Lagunas, Voto consultivo (Lima: La Oficina de los Huerphanos, I76I), 228-230.

56. Roberto Juan Katayama Omura, "El voto consultivo de Joseph Bravo de Lagunas y Castilla" (unpublished thesis, Universidad de San Marcos, n.d.).

57. Nicolás Donato, El hombre de estado (Madrid: Imprenta Real, I790), t. II, fol. 7I.

58. The influential Peruvian historian Pablo Macera credited Bravo de Lagunas with modernizing political ideology, presaging the region's move toward independence decades before the first battles were waged in the Andean highlands (Pablo Macera, Trabajos de historia [Lima: Instituto Nacional de Cultura, 1977] ).

59. Buen gusto and Classicism in the Visual Cultures of Latin America, ed. Stacie Widdifield and Paul Niell (Albuquerque: University of New Mexico Press, 2013). 
edition of Guevara's text was timely in showcasing the power of painting to shape a collective response. For Guevara, art was "a means to challenge social ills and economic failures, prescribing the controlled production of good art for the achievement of the common good" " ${ }^{60}$ Limeño artists and the patrons they portrayed were social actors working for the improvement of the common good. Their work in art, government, education, and religion suppressed public disorder to ensure the maintenance of the public good in limeño society.

Although Bravo de Lagunas was an established member of the Peruvian elite, Bermejo posits himself as an equally active participant in the body politic. Like his predecessors, Lozano and Aguilar, Bermejo regularly signed his finished portraits. In the portrait Bermejo painted for Bravo de Lagunas, a book of the scholar's library on the desk is open at a page illustrated with what seems to be an engraved portrait. The darkened rectangle at the top of the page reveals the head of a figure in a white trefoil shape with an ornamented grayscale body below it. Abstracted lines of text in two columns follow below the image in a layout commonly used in eighteenth-century printed books. Two small slips of paper are tucked into a book at the bottom of the stack; they are inscribed with the date, location, and artist's name, an artistic conceit that, while becoming more common in eighteenth-century Lima, privileged the role of the artist with an unprecedented confidence. In this instance, Bermejo not only signed his name to the canvas, he explicitly stated that he created the portrait in Lima. Bravo de Lagunas, Lozano, and Bermejo framed their recently invented philosophical and pictorial traditions in terms of history, awareness of tradition, and reflective innovation.

Prior to Daza, Lozano, Aguilar, and Bermejo, individual limeño artists rarely signed their finished works. Paula Mues Orts has observed the addition of artist signatures to specific artworks in eighteenth-century Mexico as evidence for the elevation of the social status of artists. ${ }^{61}$ As society began to value the production of individual artists, the artists themselves took ownership of the works they produced. They reiterated their highly-personalized styles with legible signatures prominently positioned in prestigious works of art. Daza, Lozano, Aguilar, and Bermejo cultivated complex working methods that pro-

6o. Alejandra Giménez-Berger, "Ethics and Economies of Art in Renaissance Spain: Felipe de Guevara’s Comentario de la pintura y pintores antiguos," Renaissance Quarterly, no. 67 (20I4): 79-II2; 8O-8I.

6I. Paula Mues Orts, La libertad del pincel. Los discursos sobre la nobleza de la pintura en Nueva España (Mexico City: Universidad Iberoamericana, 2008), 239-318. 
duced archaizing images with notable stylistic innovations. This cohort of limeno painters expanded the potential of the art of painting through the animation of pictorial space, a high degree of specificity, the reinterpretation of local pictorial precedents, and the signing of finished works. While artists like Daza and Lozano had the opportunity to contemplate and copy imported European works in the collections of their patrons, they also worked within a local painting tradition that began to see value in artists who refined unique, personal representational styles. Artistic innovation was inseparable from the collaborative networks which nurtured the development of portraiture in late-colonial Lima.

\section{Artistic Consciousness}

The capital of the Peruvian viceroyalty was home to a small but prolific group of interrelated painters whose work was socially engaged in the community that inspired it. Eighteenth- and early nineteenth-century painting in Lima was produced in an artistic community shaped by an emerging dissonance between artistic innovation and established pictorial traditions. It was not by chance that Bermejo was selected to paint the portrait of Bravo de Lagunas for the Universidad de San Marcos. Before receiving this prestigious commission, Bermejo may have been a student of Lozano, according to Wuffarden, who has observed "stylistic similarities" between the two artists on "the various occasions on which Bermejo copied the master's compositions." "62 Just two years earlier, Bermejo, who had relocated to Lima from his home town Trujillo in northern Peru, had been named Maestro mayor del arte de pintura by the sitting viceroy, Manuel de Guirior (r. 1776-1780).

As the art historical record reveals, Bermejo worked from close observation of Lozano's oeuvre in the first half of his painting career. In addition to the reinterpretation of Lozano's 175I portrait of Bravo de Lagunas, Bermejo also drew inspiration from another institutional portrait created by Lozano between 1757 and 1758. Lozano was commissioned to paint the portrait of Viceroy José Antonio Manso de Velasco (r. 1745-176I) for the Cathedral of Lima under the supervision of Archbishop Pedro Antonio de Barroeta y Ángel (fig. 9). A few

62. Luis Eduardo Wuffarden, "VI-II2 José Joaquín Bermejo," in The Arts in Latin America, I492-I820, organized by Joseph Rishel and Suzanne Stratton-Pruitt (New Haven and London: Yale University Press, 2006), 462. 
9. Cristóbal de Lozano, José Antonio Manso de Velasco, 1757-1758, Museo de Arte Religioso de la Catedral de Lima.

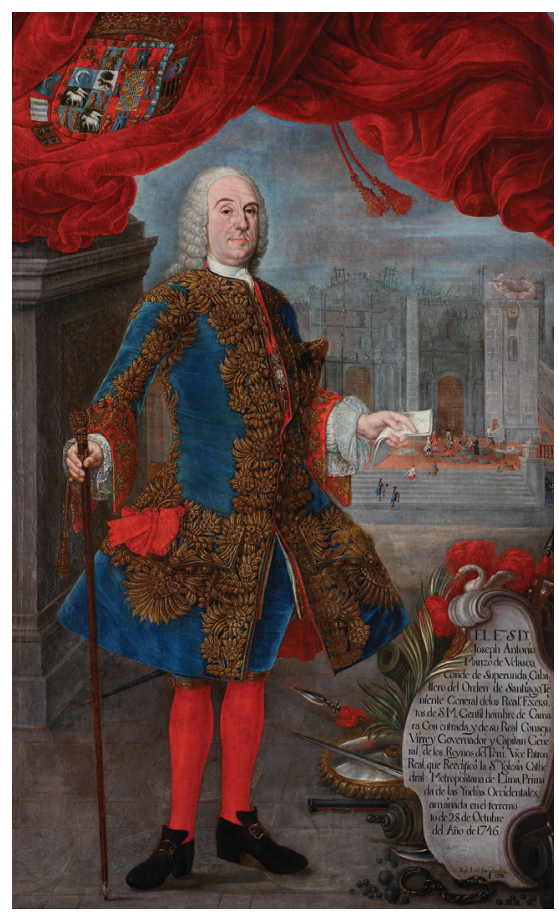

years later, the city council of Lima hired Bermejo to paint a portrait of Viceroy Manso de Velasco to add to its viceroy portrait series displayed in the ayuntamiento across the main plaza from the cathedral (fig. IO). ${ }^{63}$ Both portrait paintings were commissioned in the years following the notorious October 28, 1746 , earthquake that brought widespread destruction and significant loss of life to the Peruvian capital and its port, Callao. ${ }^{64}$

This type of large-scale institutional portrait was a well-established genre in Lima when Lozano and Bermejo completed their respective paintings. As

63. The Pinacoteca of the Municipalidad de Lima contained only one viceregal portrait dated to that year. The inventory of the Pinacoteca Municipal was published in El Comercio (Lima) January 4, I893, and is also reproduced as an appendix ("Catálogo de la Galería Municipal de Pinturas (1893) in Municipalidad Metropolitana de Lima, Pinacoteca Municipal Ignacio Merino (Lima: 2005), 330-332.

64. Charles Walker has suggested that the devastating earthquake was the impetus for an artistic revival across the city. See Charles Walker, Shaky Colonialism: The 1746 Earthquake-Tsunami in Lima, Peru, and Its Long Aftermath (Durham, NC: Duke University Press, 2008). 


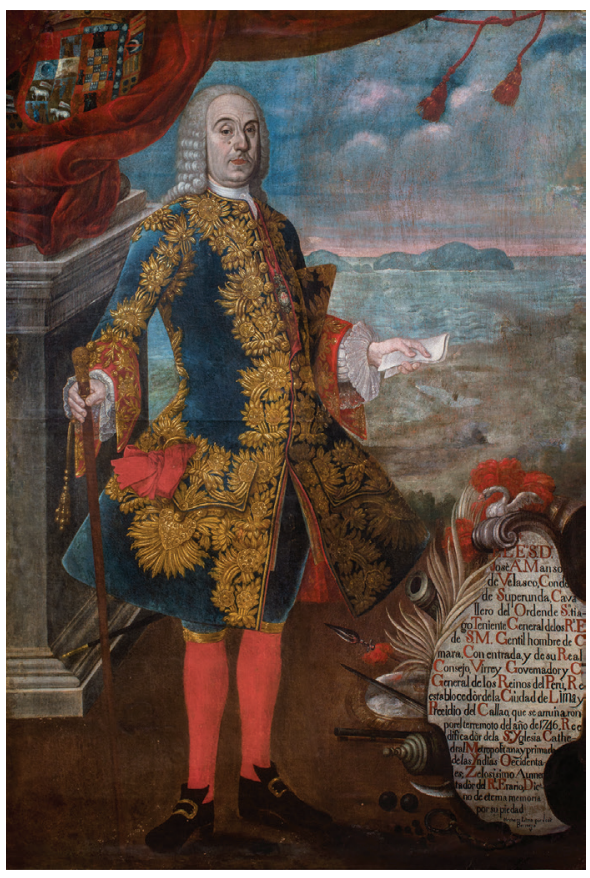

Io. José Joaquín Bermejo, José Antonio Manso de Velasco, after 1758, Museo Nacional de Arqueología, Antropología e Historia del Perú, Lima.

we have seen, institutional patronage of portraiture had its roots in sixteenthcentury Lima; however, the portraits of Viceroy Manso de Velasco signal a striking visual departure from Habsburg-era portraits produced in the Peruvian viceregal capital. ${ }^{65}$ Both portraits recuperate traditional elements of institutional portraiture: the formally dressed elite sitter, ornamental column and curtain, coat of arms, and descriptive cartouche. As we have already seen in the portraits of Bravo de Lagunas, Bermejo reinterpreted the work of his prede-

65. There is also evidence in Mexico for a visible shift away from Habsburg aesthetics in portraiture at the turn of the eighteenth century. One of the portraits of Viceroy Francisco Fernández de la Cueva (r. I702-I7II) from the municipal collection in Mexico City also incorporates a high degree of innovation within the traditional portrait format. In the portrait, the viceroy is shown in typical Habsburg fashion, the composition, style, and tone mirroring the portraits that came before it; however, there is one significant change in this image. The top right portion of the composition has been opened on to an exterior view of a harbor view with boats anchored against the horizon. After this painting, Mexican viceroy portraits gradually broke with Habsburg portrait traditions, as visualized by Juan Rodríguez Juárez's portrait of Viceroy Fernando de Alencastre Norońa y Silva from c. I7I4. (Inmaculada Rodríguez Moya, "El retrato de la élite en Iberoamerica," 83.) 
cessor. The most salient point of comparison in the two works is the standing figure of Viceroy Manso de Velasco. In both portraits, the viceroy is depicted in full-length wearing the same attire, a boldly embroidered blue velvet jacket with bright red accessories. Lozano and Bermejo position the viceroy in a three-quarter stance yet making eye contact with the viewer. Viceroy Manso de Velasco leans upon a staff of office in his right hand and proffers a letter with his left, iconographic representations of his official role as the most powerful administrative functionary in Spanish South America. The undulating red velvet curtain atop a stone pillar on the left side of the composition and a highly-ornamented inscribed cartouche in the lower right find parallels in both portraits.

While it is tempting to see Bermejo's work as a copy of Lozano's portrait, the paintings are distinctive in their iconography, composition, and formal approach. ${ }^{66}$ Lozano emphasizes the viceroy's central role in the rebuilding of the Lima cathedral following the 1746 quake. In his painting, Viceroy Manso de Velasco gestures with the letter in his left hand toward a complex scene illustrating the reconstruction of Lima's cathedral. Bermejo uses the same open composition, but to broader effect; he pans onto the Pacific Coast at Callao and the islands outside of its harbor. The resulting paintings are reflections of the individual artists' unique styles and approaches to the art of portraiture — Lozano's softer pictorial portraiture in contrast to Bermejo's heavy-handed linearity.

The two paintings depart considerably from established portrait traditions; Lozano and Bermejo situate the viceregal subject of their respective portraits in a liminal space that can be described as neither interior nor exterior. This break with tradition opens the pictorial space to an extraordinary degree. The portraits of Viceroy Manso de Velasco are as much representations of the viceroy as they are visual records of the recovery necessitated by the earthquake's pervasive dismantling of urban infrastructure. While Lozano appears to be focused on Lima's post-quake reconstruction, emblematically signified by the city's cathedral, his urban view indirectly underscores the substantial damage the city suffered for decades following the initial disaster. Lozano animates the urban landscape with several figural vignettes featuring workers, architects, officials, and urban dwellers engaged in the city's reconstruction. Viceroy Manso

66. Allan Kuethe and Kenneth Andrien, The Spanish Atlantic World in the Eighteenth Century: War and the Bourbon Reforms, 1713-1796 (Cambridge: Cambridge University Press, 2014), 173. 
de Velasco appears in one of these miniature scenes, making the image a double portrait. On the platform at the top of the stairs in front of the cathedral, the viceroy presides over a discussion with several other clerical and government officials.

Bermejo also opens up the picture plane to locate the viceregal subject of his painting in the contemporary context in which he governed. Viceroy Manso de Velasco was dedicated to rebuilding Lima and Callao in the most efficient, modern ways possible using the latest technologies, design strategies, and economic research. Bermejo depicts the devastated port of Callao as a blank slate, awaiting improvement through Bourbon reconstruction. ${ }^{67}$ Viceroy Manso de Velasco, in collaboration with local officials elected to install a modern defensive structure in the devastated port community. For decades, Callao, like other Pacific ports, had existed under threat of British naval antagonism, piracy, and contraband trade that escalated throughout the eighteenth century. On August I, 1747, the first stone was laid at the new Real Fortaleza at Callao, sponsored by the viceroy's office and designed by Louis Godin (I704-1760), a French mathematician and astronomer living in Lima. ${ }^{68}$ Bermejo, as a member of the Cuerpo Real de Ingenieros, would have had access to the fortress construction project, observing Viceroy Manso de Velasco's personal leadership role in the field during the reconstruction process. ${ }^{69}$

Detailed comparison of the works demonstrates the artistic originality present in both paintings; however, the similarities between them point to a close working relationship between Lozano and Bermejo. Bermejo and Lozano both sought artistic innovation that produced a unique pictorial style in an art market dominated by patrons devoted to institutional continuity through the period of Spanish Bourbon recolonization. These artists prove to be apt choices for representing Bravo de Lagunas and Manso de Velasco, viceroys who played vital roles in modernizing visual aesthetics in Lima during the years fol-

67. José Antonio Manso de Velasco, Relación que escribe el Conde de Superunda Virrey del Perú (Madrid: Biblioteca Nacional de España, Mss/ı3986), fols. ı-20.

68. Juan Manuel Zapatero, El Real Felipe del Callao: Primer Castillo de la "Mar del Sur" (Madrid: Madrid Servicio Histórico Militar, 1983); Felipe de la Barra, Monografía histórica del Real Felipe del Callao y guía del Museo Histórico-Militar (Callao: Centro de Estudios Histórico-Militares del Perú, 1957).

69. Emilio Harth-Terré and Alberto Márquez Abanto, Pinturas y pintores en Lima virreinal (Lima: Librería e imprenta GIL, I964). See also Alicia Cámara, Los ingenieros militares de la monarquía hispánica en los siglos XVII y XVIII (Madrid: Ministerio de Defensa, 2005). 
lowing the 1746 earthquake. ${ }^{70}$ The artists and their patrons seemed to have taken cues from each other; in politics and in painting, "break and recuperation" were interdependently reliant upon each other for achieving the desired effect. ${ }^{71}$ Pictorial illusionism sought to manipulate the viewer's experience of reality, an effect not dissimilar from the goals of Spanish Bourbon and limeño officials in the second half of the eighteenth century.

Lozano and Bermejo modified pictorial composition, dynamism, specificity, and historicity. This degree of experimentation was unprecedented in South American portraiture. Ilona Katzew has observed that "in the eighteenth century, Mexico saw an upsurge in portraiture associated with the economic growth of the viceroyalty, and different social groups, particularly within urban contexts, commissioned artists to paint their likenesses." ${ }^{22}$ Portraiture became more popular and widespread in South America after 1750, centuries after its popularization across Europe. At the same time Daza, Lozano, Aguilar, and Bermejo were at work on official portraits in South America, Anton Raphael Mengs (1728-1779) became the court portraitist for the Spanish monarchy in the service of Charles III. Mengs valued emulation as an artistic strategy in his work at court. In his extensive writings on aesthetic theory, Mengs explains that the art of painting generally requires the imitation of successful predecessors. Furthermore, he states that the successful artist "effectively studies and observes the productions of great men with the desire for imitating them mak[ing] himself capable of producing works which resemble them." ${ }^{3}$ The surviving pictorial evidence indicates that historical emulation was a pictorial strategy that shaped the work of Lima's predominant eighteenth-century portraitists. However, though the genre of portraiture was as popular in Latin America as it was in Europe, these artists did not slavishly copy European models nor did sitters demand portraits fashioned after European trends. Le Brun's portrait of

70. Charles Walker, Shaky Colonialism, 77-85.

7I. Ann Laura Stoler, Carnal Knowledge and Imperial Power (Durham, NC: Duke University Press, 2002), 6I-62.

72. Beginning with the foundational work of George Kubler, art historians have grappled with describing the relationship between American and European cultural production during the first decades after contact and into the Spanish colonial period. George Kubler, The Art and Architecture of Ancient America: The Mexican, Maya, and Andean Peoples (Baltimore: Penguin Books, 1962); Painted in Mexico, 317.

73. Anton Raphael Mengs, The Works of Anthony Raphael Mengs, vol. 2 (London: Don Joseph Nicholás Azara, I796), I06. 
Louis XIV or the softly opulent royal portraits by Nicolas de Largillière in the collection of Viceroy Oms and later Bravo de Lagunas were accessible to Daza and Lozano. Instead, Daza, Lozano, Aguilar, and Bermejo often looked to each other and the portraits produced locally for over two hundred years as they developed new forms of portrait representation. Historian David Brading pointedly summed up American creative responses to shifts in colonial governance when he observed creole and Spanish academics and officials in colonial South America "creating an intellectual tradition that was original, idiosyncratic, complex, and distinct from any European model." 74 Lima's portraitists had to sustain their creative pursuits within parameters that continued to satisfy the demands of their patrons, while appearing relevant in the context of contemporary events.

Artists in Spain confronted similar challenges. Working at the courts of Carlos IV and Fernando VII (r. I8I3-I833), Francisco de Goya y Lucientes (I746-I828) built his career around the negotiation of tradition and innovation in particular as the favored portrait painter of the Spanish royal court..$^{75}$ His late eighteenth-century portrait of the Asturian enlightenment philosopher Gaspar Melchor de Jovellanos epitomizes the artist's romantic painterly style (fig. II). ${ }^{76}$ Goya portrays the Spanish agrarian reformer using expressive facture, compositional chiaroscuro, and abstraction of context in a sea of brushwork. The artist depicts the influential sitter's likeness in a composition shaped by artistic innovation that attracted the patronage of the Spanish monarchy, enlightenment celebrities, and Spanish elites. Here the figure of Jovellanos becomes a symbol of Spanish political upheaval in the lead-up to the Napoleonic invasion which disrupted monarchical rule in the Iberoamerican world in the early-nineteenth century. Goya's work was known across the Iberoamerican world; however, his stylistic approach did not gain traction in South America, where artists favored a more measured approach to their transformation of the genre of portraiture.

It is more than coincidental that in the same historical moment that court portraitists expanded the visual field in officially commissioned paintings,

74. David Brading, The First America: The Spanish Monarchy, Creole Patriots, and the Liberal State, I492-I867 (Cambridge University Press, I99I), 5.

75. Sarah Symmons, Goya (London: Phaidon Press, I998), 93-I46.

76. Manuela Mena Marqués, "Goya and the Dark Beauty," in Dark Romanticism: From Goya to Max Ernst, ed. Felix Krämer (Ostfildern: Hatje Cantz, 20I2), 54-75. 
DOI: http://dx.doi.org/10.22201/iie.18703062e.2018.113.2655

ARTISTIC INVENTION AS TRADITION

II. Francisco de Goya y Lucientes, Gaspar Melchor de Jovellanos, 1798 , oil on canvas, $205 \times 133 \mathrm{~cm}$, Museo del Prado, Madrid.

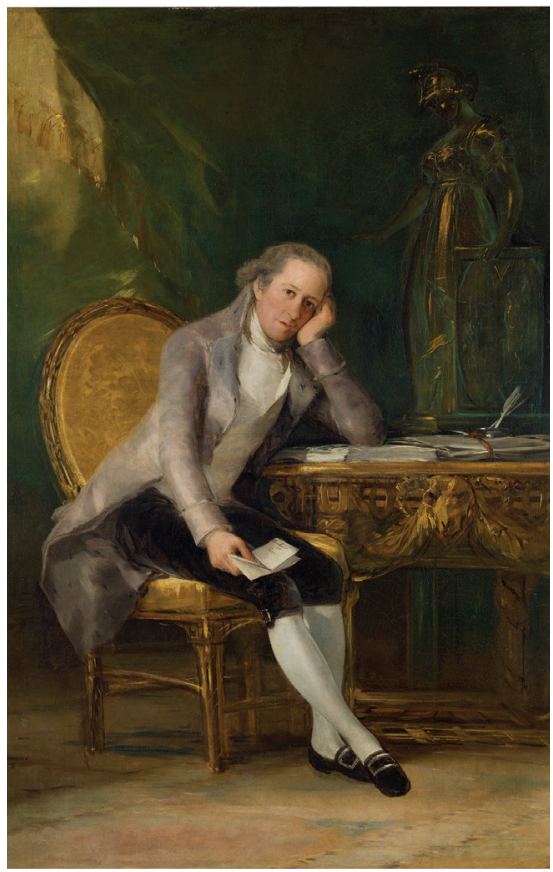

limeño politics became less insular. ${ }^{77}$ As artists working in service to the viceregal court and other influential urban institutions, Daza, Lozano, Aguilar, and Bermejo were circulating among civic and imperial officials who commissioned artworks from them. The portraitists witnessed how local and imperial officials confronted the shifting challenges of governance in a mature colony. Viceroy Manso de Velasco's term in office was overwhelmed by the task of orchestrating an effective response to the 1746 earthquake, tsunami, and aftershocks, as well as continuing reform efforts throughout the viceroyalty initiated by his predecessors. Many adjustments to economic policy, governance of the clergy, and management of indigenous welfare required a "flexible approach to governance." 78 Like the painterly process of artistic invention which depicted limeño officials in creative new visual compositions, Spanish

77. John Lynch, Spanish Colonial Administration, 1782-1810: The Intendant System in the Viceroyalty of Rio de la Plata (New York: Greenwood Press, 1969).

78. Gabriel Paquette, Enlightenment, Governance, and Reform in Spain and Its Empire, 1759-1808 (New York: Palgrave Macmillan, 2008), I32. 
imperial absolutism was evolving in the eighteenth century. Within the context of the monarchical and constitutional crises of the late-colonial period, portraits became emblematic of political transformation. Colonial governance centered upon regular political negotiation across the Iberoamerican world. Lima's civic leadership, including viceroys, clergy, and municipal officials, actively participated in global sociopolitical negotiations aimed at repairing weaknesses at the local, regional, and imperial level. Portraits, and their creators, participated in socio-political transformation across Latin America by visualizing its primary agents in innovative formats that encouraged viewers to reinterpret tradition to meet the needs of contemporary society. ${ }^{79}$

\section{The Invention of Painterly Traditions}

Discontentment among Lima’s most influential artists increased as Bourbon absolutism attempted to exert greater control over artistic production. Pictorial forms, styles, and methods which were popularized in the Habsburg era (dark compact compositions, limited color palettes, and starkly ascetic iconographies) necessitated innovation conceptualized as a way to improve upon existing painterly traditions. Daza, Lozano, Aguilar, and Bermejo used this approach to produce artworks that were relevant to Lima's contemporary social reality. Dissatisfaction among artists paralleled the volatile political atmosphere that destabilized the Viceroyalty of Peru in the late-eighteenth century. Creole and indigenous rebellions across South America, as well as invasions from aggressive European interlopers, led the Spanish monarchy to crack down on American forms of expression. ${ }^{80}$ Creole and indigenous visual and performing artforms faced severe limitation under the restrictions of Bourbon absolutism. ${ }^{8 \mathrm{I}}$ For the parties invested in guarding the precarious stability of the colonial bureaucracy, the maintenance of cultural traditions appeared to strengthen the colonial social order. ${ }^{82}$

79. Pérez and Quezada, De novoshispanos a mexicanos.

80. Resistance, Rebellion, and Consciousness in the Andean Peasant World, I8th to 20th Centuries, ed. Steve Stern (Madison: University of Wisconsin, 1987); Charles Walker, The Tupac Amaru Rebellion (Cambridge: Harvard University Press, 2014).

8I. David Garrett, The Shadows of Empire, The Indian Nobility of Cuzco, 1750-1825 (Cambridge: Cambridge University Press, 2005).

82. Indigenous imagery was replaced by portraits of the king following the sentencing of Tupac Amaru in the $178 \mathrm{os}$. Formal declarations stated that all paintings depicting indigenous traditions 
However, as Juan Carlos Estenssoro has demonstrated, some creative limeños succeeded in bringing new forms of cultural expression to life in the viceregal capital during this period. ${ }^{83}$ Daza, Lozano, Aguilar, Bermejo, and their successors crafted timeless visual identities for the limeño powerbrokers who helped to shape the Iberoamerican empire in its twilight. Their creative processes produced bodies of work that reasserted the cultural relevance of historical art collections which had accumulated in the viceregal capital for two hundred years.

Innovation within the traditional genre of portraiture came about through a collaborative process of experimentation among artists and patrons across space and time. Daza, Lozano, Aguilar, and Bermejo rose to prominence in Lima as individual artists before the foundation of art academies. Their ability to work collectively and reflexively simultaneously recalled the master/ apprentice relationships of the guild system and presaged the academic education which would dominate artistic practice in the nineteenth century. ${ }^{84}$ Although this group of limeño artists was constrained by stylistic and compositional standards that visually reiterated the authority and relevance of the institutions that commissioned official portraits from their workshops, they exhibited a striking degree of pictorial invention.

Daza, Lozano, Aguilar, and Bermejo augmented the open compositional spaces in their paintings by introducing pictorial dynamism to the genre of portraiture for the first time in South America. The animation of the portraits of Bravo de Lagunas and Manso de Velasco, for example, through the fluttering pages of books, blowing tassels, and billowing curtains, provocatively manipulates the boundaries of decorum. Daza, Lozano, Aguilar, and Bermejo exhibit what Clara Bargellini has described as the distinct artistic ability to incorporate "traditional conventions, established as far back as the sixteenth century,

"be indefectibly erased, and if painted on walls of houses, churches, monasteries, or hospitals, they were to be replaced by images of the current king". See Cecilia Méndez, The Plebian Republic, The Huanta Rebellion and the Making of the Peruvian State, I820-1850 (Durham and London: Duke University Press, 2005), I03.

83. Juan Carlos Estenssoro Fuchs, "Modernismo, estética, música y fiesta: elites y cambio de actitud frente a la cultura popular. Perú 1750-1850," in Tradición y modernidad en los Andes, ed. Enrique Urbano (Cusco: Centro Bartolomé de las Casas, I992), I8I-I95.

84. María Concepción García Sáiz, "Artisans and Artists in Ibero-America from the Sixteenth to the Eighteenth Century," in The Arts in Latin America, I492-I820, 89; Paula Mues Orts, "Illustrious Painting and Modern Brushes: Tradition and Innovation in New Spain," in Painted in Mexico, 52-77. 
with fresh coloring and expression for new individual and group needs". ${ }^{85}$ The artists, however, were careful not to undermine the somber nature of the genre by pushing the limits of the acceptable beyond the bounds of established tradition, just as Hobsbawm outlines in his formulation of invented traditions. Successful portrait artists created commemorative images that integrated a closely observed visual likeness with a distinctive interpretation of contemporary events. Portraiture as a long-standing genre is marked by its conservatism; therefore, limeño portraitists had to showcase contemporary events while alluding to the timelessness of the genre by retaining some pictorial continuity with previous examples. The resulting documentary images supported the sitter's public persona and extended the life of the commissioning institution.

Bravo de Lagunas had commissioned Lozano to restore his historical and contemporary art collection, as well as to create his portrait, following the earthquake of 1746 . Before the quake, Bravo de Lagunas had accumulated one of the largest art collections in Lima, including works by limeño, Spanish, Flemish, Italian, French and British masters. ${ }^{86}$ As Lozano set to work revitalizing the collection, he absorbed the technical nuances of the local and transcontinental art historical lineage laid out before him. Daza, Lozano, Aguilar, and Bermejo were not the first artists to collaborate in early modern South America; nevertheless, this group constitutes the first known artistic lineage of named artists who worked together and referenced each other's artwork as part of their creative process.

The invented traditions we have observed in the portraits of late-colonial Lima embody a spirit of innovation and intellectual curiosity. The portraits are not conventional, routine, or technical material experiments; rather they are ideologically significant reflections on the role of visual representation in the Bourbon reform period. Local limeño artists began to adjust the representation of the elite body in portraiture to reflect the subtle disintegration of the concept of a unified colonized society during the late eighteenth-century Bourbon recolonization effort. The followers of Daza, Lozano, Aguilar, and Bermejo, such as Pedro Díaz (c. I770-1815), who went on to found one of

85. Clara Bargellini, "Asia at the Spanish Missions of Norther New Spain," en Asia and Spanish America: Trans-Pacific Artistic and Cultural Exchange, 1500-1850, Papers from the 2006 Mayer Center Symposium at the Denver Art Museum, ed. Donna Pierce (Denver: Denver Art Museum, 2006), 332.

86. Luis Eduardo Wuffarden, "Avatares del 'bello ideal': modernismo clasicista versus tradiciones barrocas en Lima, 1750-1825," in Ramón Mujica Pinilla ed., Visión y símbolos del virreinato criollo a la República peruana (Lima: Banco de Crédito, 2006), II4. 
the first art academies in South America and the famous portraitist of the revolutionary period José Gil de Castro (I785-I84I) continued to explore what Ann Laura Stoler has described as "a tension between innovation and the reiteration of tradition" which animated late-colonial portraiture in Lima. ${ }^{87}$ By reconsidering the potential of portraiture to engage diverse audiences in debates regarding the nature of Spanish colonialisim that shaped the late-colonial period, we can begin to untangle the genre from the interpretive constraints that have historically made of portraits the tacit agents of imperial reform. is

87. Ann Laura Stoler, Carnal Knowledge, 6I-62. 